(HWISALADING ROOM

Renaiflance a Reformation

A bulletin with news of interest to Toronto scholars working in the fields of the Renaissance and Reformation. Send any items to N.Z. Davis, Department of Political Economy, University of Toronto.

eral

ence

December 7-19--..---Machiavelli's Mandragola in English (postponed from November), directed by Jacke Morbin, Colonnade Theatre (925-4573), 9:00 pom。

Thursday, January 7--Professor M.A. Screech of University College, London and Visiting Professor of French at the University of Western Ontario will address the Alliance Francaise on "L'Esprit Comique de Rabelais", 8:30., room 562 Education Centre, 155 College Street (admission for non-members is 75 \&, for students 25 ф).

January 8-__- Professor Screech will lecture to the Graduate School at

3 pom。, University College.

January-- An interesting collection of Renaissance bronzes, purchased in London, can be seen at the Laing Galleries, 194 Bloor Street West。 Mr。 Laing is now organizing the exhibition. Friday, January 29---Informal luncheon of Toronto Renaissance and Reformation? Colloquium, Faculty Club, 12:15-2:00。

\title{
I SOME ITALIAN MATERIALS AT THE PONTIFICAL INSTITUTE
}

Although primarily interested in the mediaeval period, the Institute of Mediaeval Studies has the following items in the Renaissance period not held by the University Library: seventeen manuscripts on microfilm of Petrarch's Secretum, a complete set (1947-) of the Rivista di Storia della Chiesa in Italia with its indespensable bibliography on Italian Church history including Protestant materials, the Opera Omnia (1557) of Giovanni Pico della Mirandola, the Opera Omnia (Basel, 1567) of Pietro Pomponazzi, several sixteenth-century works of Pomponazzi's major antagonist, Agostino Nifo (Niphus), several sixteenth-century editions of the works of Tommaso de Vio (Gaetano), and the complete works of Robert Bellarmine. The Mediaeval Institute library also has a handsome facsimile edition of the opera Omnia (1702-1710) of Erasmus, which the University of Toronto Iibrary has in the original. Finally, the only copy on campus that I could find of F。C. Church's fundamental Italian Reformers $(1534-1564)$ is in St。Michael's College library。

Paul Grendler

\section{THE WILI COLLECTION AT THE UNIVERSITY LIBRARY}

The collection of the late JoStanley Will, former Professor of French at the University of Toronto, has approximately 12,000 books. This is one of the largest purchases made by the University Library in recent years. It is a rich addition to the Library's holdings in French literary, religious, political and social history from the end of the Middle Ages to the 20th century. Included are many essential reference works on French literature and especially on French Protestantism (such as Haag"s La France Protestante, back issues of the Bulletin de la société

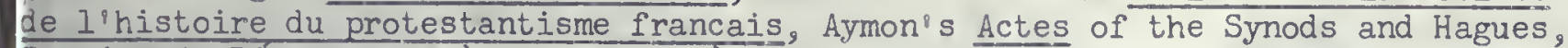
Synodes du Désert, etc。)

Approximately 380 works in the Will Collection were printed before 1700 . A substantial proportion of these are edicts, memoirs, occasional pieces and religious tracts pertaining to the fortunes of French Protestantism from the outbreak of the Religious Wars through the 17 th century. 
